\section{Biologia Futura}

https://akademiai.com/loi/019

\title{
Comet assay study of the genotoxic effect of T-2 and HT-2 toxins in chicken hepatocytes
}

\author{
Rubina Tunde Szabó ${ }^{1}$, Mária Kovács-Weber ${ }^{1}$, Márta Erdélyi ${ }^{2}$, \\ Krisztián Balogh ${ }^{2,3}$, Natasa Fazekas ${ }^{1}$, Ákos Horváth ${ }^{4}$, \\ Miklós Mézes ${ }^{2,3}$ and Balázs Kovács ${ }^{4}$
}

\section{Original Article}

Cite this article: Szabó RT, Kovács-Weber M, Erdélyi M, Balogh K, Fazekas N, Horvá Á, Mézes M, and Kovács B. 2019. Comet assay study of the genotoxic effect of T-2 and HT-2 toxins in chicken hepatocytes. Biol. Fut. 70, 330-335.

Received: 15 August 2019

Accepted: 10 November 2019

\section{Keywords:}

T-2/HT-2 mycotoxin, visual evaluation, CometScore, poultry, toxicity

${ }^{1}$ Institute of Animal Husbandry, Faculty of Agricultural and Environmental Sciences, Szent István University, Páter Károly str. 1, H-2100 Gödöllo, Hungary

${ }^{2}$ Department of Nutrition, Faculty of Agricultural and Environmental Sciences, Szent István University, Páter Károly str. 1, H-2100 Gödöllo, Hungary

${ }^{3}$ MTA-KE-SZIE Mycotoxins in the Food Chain Research Groups, Kaposvár University, Guba Sándor str. 40, H7400 Kaposvár, Hungary

${ }^{4}$ Department of Aquaculture, Institute of Aquaculture and Environmental Safety, Faculty of Agricultural and Environmental Sciences, Szent István University, Pater Karoly str. 1., H-2100 Gödöllo, Hungary

\section{DOI: $10.1556 / 019.70 .2019 .37$}

Background and aims: The aim of this study was to verify that the comet assay can be used to investigate the DNA damaging effects of T-2 and HT-2 toxins in the liver of broiler chickens. The comet assay is a favorable genotoxic analysis because it is cheap, simple, and can be used in many organisms and different tissues. Materials and methods: Male broiler chickens were fed with T-2/HT-2 toxins-contaminated diet for 14 days. The comet assay was successfully adapted to chicken liver cells, and the DNA damage was determined by a decrease in the comet parameter (DNA \% in the tail) in the experimental groups. Results: The method of evaluation was found to be critical because DNA damage could not be detected exactly using the CometScore software, due to inaccurate separation of head and comet. However, this problem can be solved by visual evaluation. Conclusion: In the case of the visual evaluation, each toxin-treated group differed significantly from the control group, indicating that the assay can be useful for the assessment of primary DNA damage caused by T-2/HT-2 toxins.

\section{INTRODUCTION}

T-2 and HT-2 toxins belong to the type A trichothecenes (Shokri et al., 2000; Yang et al., 2016), which are apolar compounds, therefore easily pass through the cell membrane. Mostly, the necrotrophic polyphagous phytopathogenic Fusarium moulds, such as Fusarium sporotrichoides, Fusarium poae, and Fusarium graminearum, are present in the temperate zone, and these produce T-2 toxin (Somosköi et al., 2012).

$\mathrm{T}-2$ toxin is known to be the most toxic mycotoxin with a trichothecene structure (Escrivá et al., 2015; Osselaere et al., 2013). HT-2 toxin has been identified as the major metabolite of T-2 toxin in vivo and in vitro with similar toxicity (Yang et al., 2016). Many undesirable effects of the T-2 mycotoxin were already shown: inducing apoptosis, obstructing cell growth, restraining protein synthesis, immunosuppression, and fertility disorders and enhancing the formation of reactive oxygen species (Chen et al., 2008; Horvatovich et al., 2013). Vomiting, diarrhea, and mucosal irritations were noticed by both animals and humans after consuming cereal grains contaminated with T-2 toxin (Horvatovich et al., 2013). The International Agency for Research on Cancer (IARC) ranks the T-2 toxin among category 3, which means that it is a non-classified human carcinogenic (IARC, 2015).

T-2 toxin shows high affinity for transpeptidases, an important subunit of the ribosome; therefore, it blocks protein synthesis and indirectly DNA and RNA syntheses (Escrivá et al., 2015). However, its genotoxic nature and the process of DNA damage have not been fully uncovered, yet (Franki et al., 2006; Hafner et al., 2012; Horvatovich et al., 2013). According to the aforementioned studies, nuclear damage could manifest in different ways: chromosome aberrations, micronucleus interchanged or sister chromatid exchange, non-planned DNA synthesis, chromosome fracture, or formation of DNA adducts (Escrivá et al., 2015; Hafner et al., 2012).
Author for correspondence:

Dr. Mária Kovács-Weber

e-mail: weber.maria@mkk.szie.hu

(C) 2019 The Author(s)
This is an open-access article distributed under the terms of the Creative Commons Attribution 4.0 International License, which permits unrestricted use, distribution, and reproduction in any medium, provided the original author and source are credited, a link to the CC License is provided, and changes - if any - are indicated. (SID_1) 
The study of Hafner et al. (2012) showed the migration of DNA in the spleen of roosters after 17-day-long T-2 toxin exposure. Less than $1.5 \mathrm{mg}$ of $\mathrm{T}-2$ toxin $/ \mathrm{kg}$ feed DNA breaking was not visible by the comet assay in leukocytes isolated from the spleen. However, measurable DNA damage was found when the contamination level was much higher, i.e., $13.5 \mathrm{mg}$ T-2 toxin $/ \mathrm{kg}$ feed. These results suggest the possibility of single- or double-strand breaking of DNA as the genotoxic effect of T-2 toxin (Rezar et al., 2007).

Sokolovic et al. (2007) used the comet assay to investigate the T-2 toxin-induced DNA damage in chicken lymphocytes. T-2 toxin was applied by gavage directly into the craw of chicken in a dose of $0.5 \mathrm{mg} / \mathrm{kg}$ body weight. Significant DNA breakage was found as compared to the control group after $24 \mathrm{hr}$. The generally accepted No Observed Adverse Effect Level in poultry is $0.5 \mathrm{mg} \mathrm{T}-2$ toxin/feed $\mathrm{kg}$ (Osselaere et al., 2013), while the $\mathrm{LD}_{50}$ value is $4.97 \mathrm{mg} / \mathrm{kg}$ in chicken (Sokolovic et al., 2008).

DNA damage can be measured by different methods, such as the PCR-based ones, flow cytometry, and Halo assay. The comet assay can detect DNA damage in a single cell - also known as single-cell gel electrophoresis - so the frequency of the damage in a cell population can be predicted in a relatively simple and sensitive way (Augustyniak et al., 2014; Kent et al., 1995). The presence of genotoxic materials in the environment can also be detected using this method (Azqueta et al., 2009). It is suitable for quantitative measurements of direct DNA damage, and is one of the best methods for the analysis of single- or double-strand DNA breaks or oxidative DNA damage (Dhawan et al., 2009; Kent et al., 1995). The comet assay was also used for the analysis of DNA damage of ionizing radiations, freezing, and thawing in chicken liver cells (Duarte et al., 2009; Faullimel et al., 2005) during storage, and also effects of different carcinogens (Williams et al., 2014), such as aflatoxin $\mathrm{B}_{1}$ (Williams et al., 2011) in chicken embryo liver.

The aim of this study was to evaluate the effect of T-2 toxin on DNA damage in chicken liver cells. The effect of T-2 toxin on DNA damage has not been analyzed in chicken liver up to date; yet, the liver is the major site of the biotransformation of T-2 toxin and some of its bioactive metabolites, such as HT-2 toxin, which is equally toxic as T-2 toxin (Eriksen \& Alexander, 1998).

\section{MATERIALS AND METHODS}

\section{Ethical issues}

Feeding experiments were carried out according to the general rules of animal experiments and followed the $3 \mathrm{R}$ criteria (replacement/reduction/refinement). The experiment was authorized by the Directorate of Food Safety and Animal Health of Governmental Office of Pest County (license number: XIV-I-001/1880-5/2012).

\section{Animal design, mycotoxin production, and experimental contamination}

A total of 20 Cobb 540 male broiler chickens at 14 days of age (body weight: $395.85 \pm 47.72 \mathrm{~g}$ ) were investigated.
Four (experimental: Eg1, Eg2, Eg3 and control) groups were formed, with five chickens in each. The animals were fed with commercial broiler starter feed (13.4 MJ/kg AME, $20 \%$ crude protein, $10 \%$ ether extract, $3.5 \%$ crude fiber, $35 \mathrm{mg} / \mathrm{kg}$ vitamin E, and $0.25 \mathrm{mg} / \mathrm{kg}$ selenium). The nutrient content of this feed met the requirements for broiler chickens (Hungarian Feed Code, 2004). The experiment lasted 14 days and started at 14 days of age. The animals fed the mycotoxin-contaminated diets continuously during the trial.

T-2 toxin was produced under controlled laboratory conditions on corn grits by $F$. sporotrichoides NRRL 3229 strain (Agricultural Research Service Culture Collections, National Centre for Agricultural Research, Peroria, IL, USA) by the method of Fodor et al. (2006). T-2 toxin-contaminated corn grit was mixed with the feed before the trial. Measured mycotoxin content of the experimental diets is presented in Table 1.

The feed sampling was immediately after the preparation of the diets. T-2 and HT- 2 toxin concentrations of the feed were measured with three replicates by the method of Trebstein et al. (2008) with high-performance liquid chromatography (HPLC) method with immunoaffinity cleanup. The detection limit of T-2 and HT-2 toxin was $0.02 \mathrm{mg} / \mathrm{kg}$ feed.

Chickens were euthanized by cervical dislocation, and liver samples were collected post mortem, after the necropsy. The samples were placed in Eppendorf tubes and were stored for not more than $20 \mathrm{~min}$ on ice before analysis.

\section{Comet assay}

To demonstrate the effect of T-2/HT-2 toxin on the chicken liver cells, the comet assay was performed under alkaline conditions according to Singh et al. (1988) and Devaux et al. (1997) with minor modifications. All the chemicals used were obtained from Sigma (St. Louis, MO, USA). Single-cell suspensions were prepared by diluting the liver samples with phosphate buffer solution (PBS; 1:100, v/v; $10 \mathrm{mM}$; $\mathrm{pH}: 7.3$ 7.5), then the samples were homogenized (Cordless Microtube Homogenizer, Fisher Scientific Co., Pittsburgh, PA, USA). Hydrogen peroxide $(10 \mu \mathrm{l}, 3 \% \mathrm{v} / \mathrm{v})$ was used to create the positive control samples (group $\mathrm{C}+$ ). First, the slides were covered with $0.8 \%(\mathrm{w} / \mathrm{v})$ normal melting point agarose. When the first layer had solidified 1\% (w/v), low melting point agarose was spread on the slides, diluted with the same volume of cell suspension. This layer was allowed to solidify onto the slides by placing them on melting ice for $5 \mathrm{~min}$.

Table 1. Measured mycotoxin content of the experimental diets

\begin{tabular}{lcc}
\hline & \multicolumn{2}{c}{$\begin{array}{c}\text { Mycotoxin content of the feed } \\
(\text { mean } \pm S D)\end{array}$} \\
\cline { 2 - 3 } & $\begin{array}{c}\mathrm{T}-2 \text { toxin } \\
(\mathrm{mg} / \mathrm{kg})\end{array}$ & $\begin{array}{c}\text { HT-2 toxin } \\
(\mathrm{mg} / \mathrm{kg})\end{array}$ \\
\hline Experimental group & $<0.02$ & $<0.02$ \\
Control & $0.127 \pm 0.033$ & $0.088 \pm 0.023$ \\
Eg2 & $0.235 \pm 0.055$ & $0.149 \pm 0.010$ \\
Eg3 & $0.989 \pm 0.168$ & $0.570 \pm 0.061$ \\
\hline
\end{tabular}

Note. SD: standard deviation; Eg1: Experimental group 1; Eg2: Experimental group 2; Eg3: Experimental group 3. 
Finally, the third layer of $0.5 \%(\mathrm{w} / \mathrm{v})$ low melting point agarose gel was added to cover the second layer and again, allowed to solidify for $5 \mathrm{~min}$. Slides were immersed to a freshly prepared lysis solution $(2.5 \mathrm{M} \mathrm{NaCl}, 0.1 \mathrm{M}$ EDTA, $0.01 \mathrm{M}$ Tris, and $\mathrm{pH}$ : 10) at $4{ }^{\circ} \mathrm{C}$ for at least $1 \mathrm{hr}$. After the lysis of the cells, the slides were transferred to an electrophoresis tank filled with electrophoresis buffer $(0.3 \mathrm{M} \mathrm{NaOH}$ and $1 \mathrm{mM}$ EDTA). After the electrophoresis $(20 \mathrm{~V}, 300 \mathrm{~mA}$, and $24 \mathrm{~min})$, the slides were rinsed with a neutralizing solution (0.4 M Tris and $\mathrm{pH}: 7.5)$. This step was repeated after $5 \mathrm{~min}$. Up to this point, all activities were carried out in the dark. Each slide was stained with $50 \mu$ of ethidium bromide $(0.05 \mathrm{mM})$ and was covered with a coverslip. Digital images of the slides were made by a QCapture MicroPublisher 3.3 RTV camera attached to a fluorescent microscope (Nikon Eclipse E600, Nikon Instruments, Melville, NY, USA) equipped with a $20 \times$ magnification objective. At least 150 cells were analyzed in each control and treated group. DNA damage was evaluated by CometScore software (TriTek, Tritek Corporation, VA, USA), and percent DNA in the tail was used as the principal parameter.

The results were also analyzed visually, as in case of high-scale damage visual analysis is able to detect the degree of damage. Visual analysis was performed according to the method of Singh et al. (1988) and Collins et al. (1997). Comets were evaluated individually on a $0-4$ scale during the analysis, based on the quantity of DNA fragments in the tail of the comet. At least 100 cells in each group were evaluated as was proposed by Horvatovich et al. (2013).

\section{Statistical analysis}

The statistical analysis was carried out using the R software package (R Core Team, 2013). Normal distribution of the groups was checked by Shapiro-Wilk test. The DNA\% in tail values of the treated, positive control, and control groups was compared with non-parametric Kruskal-Wallis test with $p \leq .05$ level of significance.

\section{RESULTS}

There are many comet assay parameters as Olive tail moment, tail length, lenght/height, tail extent, tail optical intensity, and head DNA in the literature (Kumaravel et al., 2009); however, the percentage of DNA in the tail of comet is the most informative and frequently used parameter (Collins, 2004; Tice et al., 2000). Based on the method of the evaluation, different tendencies were found. The evaluation of CometScore showed a significant variation in the toxin-treated groups. T-2/HT-2 toxin treatment had a significant effect $(p<.001)$ on the DNA damage. DNA damage was the lowest in the control group (C), whereas T-2 and HT-2 toxins caused an increase in DNA damage at the dose of $0.215 \mathrm{mg} / \mathrm{kg}$; thus, Eg1 significantly differed from all the other groups (Table 2). T-2 and HT-2 toxins had a negative effect on DNA damage at the dose of $0.384 \mathrm{mg} / \mathrm{kg}(\mathrm{Eg} 2)$; however, the mean value of DNA $\%$ in the tail was lower as compared to the Eg1 group. The Eg2 group significantly differed from both the Eg1 and Eg3 groups $(p<.001)$. In the case of the highest dose, the toxin treatment did not affect the DNA migration. However, the Eg3 group had the greatest range regarding the comet parameter (Fig. 1).

In parallel with the evaluation by the CometScore software, visual evaluation was also performed on the $0-4$ scale (Table 2). The visual evaluation also proved that the mycotoxin treatment has a significant effect on DNA damage $(p<.001)$ by Kruskal-Wallis test. T2 and HT-2 toxins induced a significant increase in the DNA damage in the Eg1 group. A high extent of DNA damage was also detected in the samples of the Eg2 group but the average score was lower than in the Eg1 group. These directions of the difference were similar to the results of the Comet Score evaluation. The $\mathrm{Eg} 2$ group revealed a significant difference from the $\operatorname{Eg} 1$ group $(p=.006)$ and also from $\operatorname{Eg} 3$ groups $(p=.001)$. High DNA fragmentation was found in the Eg3 group by visual evaluation. The average score in the Eg3 group was higher than in Eg1 or Eg2 group. This result was supported by the image analyses of comets, which proved that the head and the tail were not clearly distinct.

\section{DISCUSSION}

The comet assay is a frequently used method in human cells, laboratory, and non-laboratory animals for the evaluation of DNA damage. The application of this method is wide also in poultry species, for instance in quail meat, chicken embryo liver, spleen, and blood. The comet assay has not been used previously for the evaluation of the DNA damaging effects of mycotoxins in chicken liver. According to our experiences with this method, dilution rate is an important factor with the

Table 2. Results of the comet assay parameter (DNA\% in the tail) and the visual evaluation

\begin{tabular}{|c|c|c|c|c|}
\hline \multirow[b]{2}{*}{ Experimental group } & \multicolumn{2}{|c|}{ DNA $\%$ in the tail $(\%)$} & \multicolumn{2}{|c|}{ Visual evaluation (point) } \\
\hline & Mean & $S D$ & Mean & $S D$ \\
\hline Control (C) & $0.11^{\mathrm{a}}$ & 0.0002 & $0.13^{\mathrm{a}}$ & 0.3 \\
\hline Positive control $(\mathrm{C}+)$ & $0.946^{\mathrm{b}}$ & 1.591 & $3.67^{\mathrm{c}}$ & 0.7 \\
\hline Eg1 & $4.319^{\mathrm{c}}$ & 5.396 & $3.50^{\mathrm{c}}$ & 0.8 \\
\hline Eg2 & $1.142^{\mathrm{b}}$ & 1.194 & $3.10^{\mathrm{b}}$ & 0.9 \\
\hline Eg3 & $0.445^{\mathrm{a}}$ & 1.709 & $3.60^{\mathrm{c}}$ & 0.8 \\
\hline
\end{tabular}

Note. Different superscript letters in the same column represent significant difference $(p<.05)$. SD: standard deviation; Positive control $(\mathrm{C}+)$ : control samples treated with hydrogen peroxide $(3 \% \mathrm{v} / \mathrm{v})$; Eg1: $0.127+0.088 \mathrm{mg} \mathrm{HT}-2 \mathrm{~kg}^{-1} ; \mathrm{Eg} 2: 0.235+0.149 \mathrm{mg} \mathrm{HT}-2 \mathrm{~kg}^{-1} ; \mathrm{Eg} 3: 0.989+0.57 \mathrm{mg}$ HT-2 kg ${ }^{-1}$. 


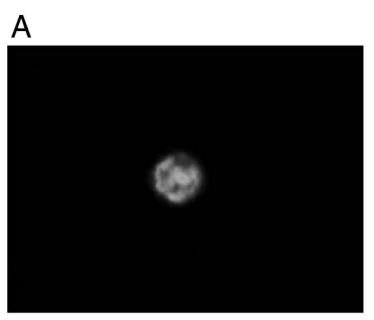

D

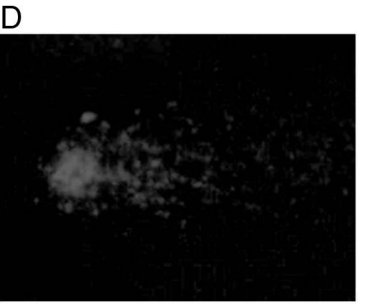

B

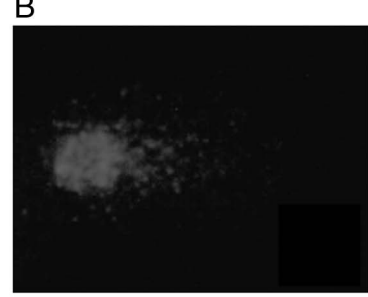

E
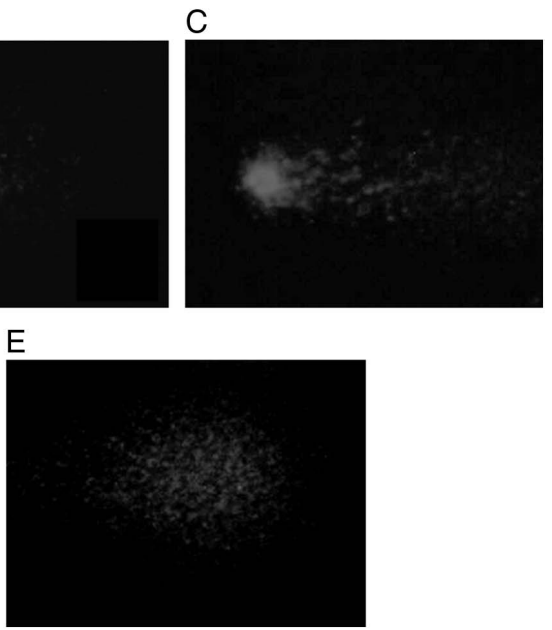

Fig. 1. Representative pictures of comet assay on the effect of different dosage of T-2 + HT-2 mycotoxins (anode to the right, ethidium bromide staining, 20× magnification). (A) Control (undamaged), (B) positive control treated with hydrogen peroxide $(10 \mu \mathrm{l}, 3 \% \mathrm{v} / \mathrm{v}),(\mathrm{C})$ Experimental group 1 (treated with $0.127 \pm 0.033 \mathrm{mg} / \mathrm{kg} \mathrm{T}-2+0.088 \pm 0.023 \mathrm{mg} / \mathrm{kg}$ HT-2 toxins), (D) Experimental group $2(0.235 \pm 0.055 \mathrm{mg} / \mathrm{kg} \mathrm{T}-2+0.149 \pm 0.010 \mathrm{mg} / \mathrm{kg}$ HT-2 toxins $)$, and (E) Experimental group $3(0.989 \pm 0.168 \mathrm{mg} / \mathrm{kg}$ $\mathrm{T}-2+0.570 \pm 0.061 \mathrm{mg} / \mathrm{kg} \mathrm{HT}-2$ toxins)

right density of the comets, the prohibition of lysis, and the overlap of the comets can be avoided. Overlapping may cause incorrect scoring (Collins, 2014). In preliminary studies, we had defined the optimal cell density, which makes the comet method applicable in chicken liver cells that made possible the following interpretation of our results (unpublished data). Dilution rates $(1: 1$ or $1: 10)$ were proposed by the standard protocol of Devaux et al. (1997). In the case of chicken blood, a 1:200 dilution rate in PBS was proposed (Sokolovic et al., 2007). However, based on our preliminary experiment, 1:100 dilution rate was applied to investigate the damage in the chicken liver cells.

$\mathrm{T}-2$ toxin is harmful $\left(\mathrm{LD}_{50}: 4.97 \mathrm{mg} / \mathrm{kg}\right)$ in poultry species. However, toxicity is lower after deacetylation, which produces the first bioactive metabolite, HT-2 toxin $\left(\mathrm{LD}_{50}\right.$ : $7.22 \mathrm{mg} / \mathrm{kg}$ ). T-2 toxin or HT-2 toxin exposure can cause adverse effects, such as oxidative stress or inhibition of protein, DNA and RNA syntheses (Leal et al., 1999; Sokolovic et al., 2008; Yang et al., 2016). In previous in vivo experiments genotoxic, no significant cytotoxic effects were observed at higher mycotoxin doses in poultry (Rezar et al., 2007). DNA damage in liver was reported in mice and rats (Atroshi et al., 1997; Rizzo et al., 1998) but limited data are available regarding poultry. In this study, we proved that T-2/HT-2 toxin has a DNA damaging effect. This effect was detected at the contamination level of $0.215 \mathrm{mg} \mathrm{T}-2 / \mathrm{HT}-2$ toxin/ $\mathrm{kg}$ feed, which was approximately the same as the maximum proposed concentration in the EU (2013/165/EU) and half of that proposed by Eriksen and Pettersson (2004) as a tolerable limit for poultry. In the case of similar dosage, more than $4 \%$ of fragmented DNA was found in the liver cells with a great deviation. At higher doses of $0.384 \mathrm{mg}$ T-2/HT-2 toxin/kg feed, the effect was also proved. However, in this case, the expected damage could not be detected by the CometScore software. At the highest dose level, i.e., $1.559 \mathrm{mg}$ T-2/HT-2 toxin/kg feed, it was unexpected that there was no significant DNA damage evaluated by the CometScore software. However, some previous studies proved that as high as $5 \mathrm{mg} \mathrm{T}-2$ toxin $/ \mathrm{kg}$ feed has a genotoxic effect in poultry species (Franki et al., 2006; Hafner et al., 2012; Rezar et al., 2007).

The comet assay is a simple method but care must be taken over practical details. This method has its advantages and boundaries as well. Collins (2014) identified some critical factors, such as agarose concentration, the density of comets, incubation time, or electrophoresis parameters. Moreover, the evaluation method is also important to draw the right conclusions. During the manual evaluation, the expert needs to mark the comet head. In case of $1.559 \mathrm{mg}$ $\mathrm{T}-2 / \mathrm{HT}-2$ toxin/kg feed, there was a problem during evaluation because in most cells only the tails were noticeable and the tail and the head were not distinct. As the head and the tail parts of the comets could not be distinguished, evaluation by the CometScore software was incorrect, and it was not possible to analyze the damaged cells by this method. In such cases, visual evaluation is necessary due to limitations of the manual comet boundary and head position selection (Horvatovich et al., 2013). Automated analysis would also be suitable, but the accuracy of the automatic comet identification is also limited at extreme high damage conditions (Gyori et al., 2014). Therefore, visual evaluation was carried out for measuring the extent of the damage. The visual analysis showed significant damage in case of all of the three mycotoxintreated groups, and the score was between 3 and 4. Our results also showed that it is beneficial to use the different evaluation methods together to get accurate information about the extent of the DNA damage. The large fan-like tail and small head (hedgehog) of the comet could be the effect of apoptosis, although this characterization may not always be accurate. For example, hedgehog comets are induced by radiation (Tice et al., 2000). We did not identify comets with this character and the applied mycotoxin doses do not cause cytotoxicity (Rezar et al., 2007). Our data add new information about the DNA damaging effect of T-2/HT-2 toxin in chicken hepatocyte cells in vivo. 


\section{CONCLUSION FOR FUTURE BIOLOGY}

According to our best knowledge, this is the first experiment, which used the comet assay to analyze the effect of the T-2 and HT-2 toxins in chicken hepatocytes successfully. The study shows the potential DNA damaging effect of the T-2/HT-2 toxin after 14 days of exposure. The method of evaluation is critical and should be based on the extension and type of the DNA damage. Maximum concentration limits proposed by the EU for T-2/HT-2 toxin $(0.25 \mathrm{mg} / \mathrm{kg}$ feed) should also be reconsidered because in this study $0.215 \mathrm{mg} \mathrm{T}-2 / \mathrm{HT}-2 / \mathrm{kg}$ feed dose had a significant DNA damaging effect.

Acknowledgments: None.

Funding Statement: The experiments were supported by the EFOP-3.6.3-VEKOP-16-2017-00008 project, co-financed by the European Union and the European Social Fund.

Ethical Statement: All applicable international and national guidelines for the care and use of animals were followed. The experiment was authorized by the Directorate of Food Safety and Animal Health of Governmental Office of Pest County (license number: XIV-I-001/1880-5/2012).

Data Accessibility: The raw generated data are available from the corresponding author $(\mathrm{MK}-\mathrm{W})$ on request.

Competing Interests: The authors declare no competing interests.

Authors' Contributions: RTS provided significant contributions to the development of comet assay and analysis of data and interpretation of the results. MK-W and MM contributed to the conceptualization and the revision of the manuscript. $\mathrm{ME}$ contributed to the conceptualization and the correction of the manuscript. $\mathrm{KB}$ contributed to conceptualization and the preparation the mycotoxin-contaminated feed. NF contributed to drafting and the correction of the manuscript. ÁH contributed to the development of comet assay. BK contributed to drafting and revision of the manuscript. RTS and MK$\mathrm{W}$ contributed equally to this work.

\section{REFERENCES}

Atroshi, F., Rizzo, A., Biese, I., Veijalainen, P., Antila, E., Westermarck, T. (1997) T-2 toxin-induced DNA damage in mouse livers: the effect of pretreatment with coenzyme Q10 and $\alpha$-tocopherol. Mol. Aspects Med. 18(Suppl. 1), 255-258.

Augustyniak, M., Orzechowska, H., Kędziorski, A., Sawczyn, T., Dole ych, B. (2014) DNA damage in grasshoppers' larvae comet assay in environmental approach. Chemosphere 96, $180-187$.

Azqueta, A., Shaposhnikov, S., Collins, A. R. (2009) DNA oxidation: investigating its key role in environmental mutagenesis with the comet assay. Mutat. Res. 674, 101-108.
Chen, J.-H., Cao, J.-L., Chu, Y.-L., Wang, Z.-L., Yang, Z.-T., Wang, H.-L. (2008) T-2 toxin-induced apoptosis involving Fas, p53, Bcl-xL, Bcl-2, Bax and caspase-3 signaling pathways in human chondrocytes. J. Zhejiang Univ. Sci. B 9, 455-463.

Collins, A. R. (2004) The comet assay for DNA damage and repair. Mol. Biotechnol. 26(3), 249-261.

Collins, A. R. (2014) Measuring oxidative damage to DNA and its repair with the comet assay. Biochim. Biophys. Acta 1840, 794-800.

Collins, A. R., Dusinská, M., Franklin, M., Somorovská, M., Petrovská, H., Duthie, S., Fillion, L., Panayiotidis, M., Raslová, K., Vaughan, N. (1997) Comet assay in human biomonitoring studies: reliability, validation, and applications. Environ. Mol. Mutagen. 30, 139-146.

Devaux, A., Pesonen, M., Monod, G. (1997) Alkaline comet assay in rainbow trout hepatocytes. Toxicol. In Vitro 11, 71-79.

Dhawan, A., Bajpayee, M., Parmar, D. (2009) Comet assay: a reliable tool for the assessment of DNA damage in different models. Cell Biol. Toxicol. 25, 5-32.

Duarte, R. C., Araújo, M. M., Salum, D. C., Marchioni, E., Villavicencio, A. L. C. H. (2009) Effects of the ionizing radiations, freezing and thawing duration on chicken liver cells quality. Radiat. Phys. Chem. 78, 631-634.

Eriksen, G. S., Alexander, J. (eds.) (1998) Fusarium Toxins in Cereals - A Risk Assessment. Nordic Council of Ministers, Copenhagen.

Eriksen, G., Pettersson, H. (2004) Toxicological evaluation of trichothecenes in animal feed. Anim. Feed Sci. Technol. 114, 205-239.

Escrivá, L., Font, G., Manyes, L. (2015) In vivo toxicity studies of fusarium mycotoxins in the last decade: a review. Food Chem. Toxicol. 78, 185-206.

Faullimel, C., Ennahar, S., Aoude-Werner, D., Guterl, P., Marchioni, E. (2005) DNA comet assay for the detection of time-temperature abuse during the storage of poultry. J. Food Prot. 68(7), 1414-1420.

Fodor, J., Németh, M., Kametler, L., Pósa, R., Kovács, M., Horn, P. (2006) Novel methods of Fusarium toxins' production for toxicological experiments. Acta Agr. Kaposvár. 10, 277-285.

Franki, T., Pajk, T., Rezar, V., Levart, A., Salobir, J. (2006) The role of dietary nucleotides in reduction of DNA damage induced by T-2 toxin and deoxynivalenol in chicken leukocytes. Food Chem. Toxicol. 44, 1838-1844.

Gyori, B. M., Venkatachalam, G., Thiagarajan, P. S., Hsu, D., Clement, M.-V. (2014) OpenComet: an automated tool for comet assay image analysis. Redox Biol. 2, 457-465.

Hafner, D., Bodnár, Zs., Horvatovich, K., Berta, G., Kovács, M. (2012) Preliminary investigations into the effect of feeding mannan oligosaccharide (MOS) on the genotoxic effect of T-2 toxin in rabbits measured by comet assay. Acta Agri Slov. 3, 351-355.

Horvatovich, K., Hafner, D., Bodnár, Zs., Berta, G., Hancz, Cs., Dutton, M., Kovács, M. (2013) Dose-related genotoxic effect of T-2 toxin measured by comet assay using peripheral blood mononuclear cells of healthy pigs. Acta Vet Hung. 61, 175-186.

Hungarian Feed Code (2004) Nutrient Requirement of Broiler Chicken, Vol. II. OMMI, Budapest, p. 352. (in Hungarian)

International Agency for Research on Cancer [IARC]. (2015) Monographs, Vols.1-112. Retrieved from https://monographs. iarc.fr/ENG/Classification/ClassificationsAlphaOrder.pdf. Accessed on: October 31, 2018. 
Kent, C. R., Eady, J. J., Ross, G. M., Steel, G. G. (1995) The comet moment as a measure of DNA damage in the comet assay. Int. J. Radiat. Biol. 67(6), 655-660.

Kumaravel, T. S., Vilhar, B., Faux, S. P., Jha, A. N. (2009) Comet assay measurements: a perspective. Cell Biol Toxicol. 25(53), 53-64.

Leal, M., Shimada, A., Ruíz, F., González de Mejía, E. (1999) Effect of lycopene on lipid peroxidation and glutathionedependent enzymes induced by $\mathrm{T}-2$ toxin in vivo. Toxicol. Lett. 109, 1-10.

Osselaere, A., Li, S. J., De Bock, L., Devreese, M., Goossens, J., Vandenbroucke, V., Van Bocxlaer, J., Boussery, K., Pasmans, F., Martel, A., De Backer, P., Croubels, S. (2013) Toxic effects of dietary exposure to T-2 toxin on intestinal and hepatic biotransformation enzymes and drug transporter systems in broiler chickens. Food Chem. Toxicol. 55, 150-155.

$\mathrm{R}$ Core Team. (2013) R: A Language and Environment for Statistical Computing. R Foundation for Statistical Computing, Vienna, Austria. Retrieved from http://www.R-project.org/

Rezar, V., Frankic, T., Narat, M., Levart, A., Salobir, J. (2007) Dose-dependent effects of T-2 toxin on performance, lipid peroxidation, and genotoxicity in broiler chickens. Poult. Sci. $86,1155-1160$.

Rizzo, A., Biese, I., Veijalainen, P., Antila, E., Westermarck, T., Atroshi, F. (1998) Mycotoxins induced DNA oxidative damage in rat liver cell. Pathophysiology 5(Suppl.1), 81.

Shokri, F., Heidari, M., Gharagozloo, S., Ghazi-Khansari, M. (2000) In vitro inhibitory effects of antioxidants on cytotoxicity of T-2 toxin. Toxicology 146, 171-176.

Singh, N. P., McCoy, M. T., Tice, R. R., Schneider, E. L. (1988) A simple technique for quantitation of low levels of DNA damage in individual cells. Exp. Cell Res. 175, 184-191.
Sokolovic, M., Garaj-Vrhovac, V., Ramic, S., Šimpraga, B. (2007) Chicken nucleated blood cells as a cellular model for genotoxicity testing using the comet assay. Food Chem. Toxicol. 45, 2165-2170.

Sokolovic, M., Garaj-Vrhovac, V., Šimpraga, B. (2008) T-2 toxin: incidence and toxicity in poultry. Arh Hig Rada Toksikol. 59, $43-52$.

Somoskői, B., Keresztes, Zs., Solti, L., Kovács, M., Cseh, S. (2012) Effect of T-2 mycotoxin on early development of mouse embryos. Magyar Állatorvosok Lapja. 134, 614-619.

Tice, R. R., Agurell, E., Anderson, D., Burlinson, B., Hartmann, A., Kobayashi, H., Miyamae, Y., Rojas, E., Ryu, J. C., Sasaki, Y. F. (2000) Single cell gel/comet assay: guidelines for in vitro and in vivo genetic toxicology testing. Environ. Mol. Mutagen. 35, 206-221.

Trebstein, A., Seefelder, W., Lauber, U., Humpf, H. U. (2008) Determination of T-2 and HT-2 toxins in cereals including oats after immunoaffinity cleanup by liquid chromatography and fluorescence detection. J. Agric. Food Chem. 56, 4968-4975.

Williams, J. G., Deschl, U., Williams, G. M. (2011) DNA damage in fetal liver cells of turkey and chicken eggs dosed with aflatoxin $\mathrm{B}_{1}$. Arch. Toxicol. 85, 1167-1172.

Williams, G. M, Duan, J.-D., Brunnemann, K. D., Iatropoulos, M. J., Vock, E., Deschl, U. (2014) Chicken fetal liver DNA damage and adduct formation by activation-dependent DNAreactive carcinogens and related compounds of several structural classes. Toxicol. Sci. 141(1), 18-28.

Yang, L., Yu, Z., Hou, J., Deng, Y., Zhou, Z., Zhao, Z., Cui, J. (2016) Toxicity and oxidative stress induced by T-2 toxin and HT-2 toxin in broilers and broiler hepatocytes. Food Chem. Toxicol. 87, 128-137. 